\title{
KONDISI SOSIAL EKONOMI DAN TINGKAT KESEJAHTERAAN KELUARGA: KASUS DI WILAYAH PESISIR JAWA BARAT
}

\author{
Socio-economic Factors and Family Welfare: The Case of Coastal Area in West Java \\ ISTIQLALIYAH MUFLIKHATII ${ }^{*}$, HARTOYO ${ }^{2}$, UJANG SUMARWAN $^{2}$, \\ ACHMAD FAHRUDIN ${ }^{3}$, HERIEN PUSPITAWATI ${ }^{2}$
}

\author{
${ }^{1}$ Program Studi Gizi Masyarakat dan Sumberdaya Keluarga, Sekolah Pascasarjana IPB \\ ${ }^{2}$ Departemen Ilmu Keluarga dan Konsumen, Fakultas Ekologi Manusia, Institut Pertanian \\ Bogor, Jalan Lingkar Kampus IPB Dramaga, \\ Bogor 16680 \\ ${ }^{3}$ Staf Pengajar Departemen Manajemen Sumberdaya Perairan, Fakultas Perikanan dan \\ IImu Kelautan, Institut Pertanian Bogor, Jalan Lingkar Kampus IPB Dramaga, \\ Bogor 16680
}

\begin{abstract}
Family welfare is influenced by socio-economic factors like sociodemographic of family, family income, and position in society. This research compared characteristics and family welfare between fishermen families and non-fishermen families in coastal West Java. This research also analyzed the effect of social economy of family toward family welfare. This research involved 280 families as samples, consist of 157 fishermen families and 123 non-fishermen families. The research conducted in eight villages of four coastal subdistricts in West Java Province. The were no significant differences on family types, father's and mother's age, value of total assets, and per capita expenditure between fishermen and non-fishermen families. Father's and mother's education of fishermen families were significantly lower than father's and mother's education of non-fishermen families. On the contrary, family size and per capita income in fishermen families significantly were higher than nonfishermen families. Fishermen families had higher level welfare than non-fishermen families used World Bank and BPS's poverty line indicators, but by BKKBN, poverty household criteria, and socio-metric indicators fishermen families had lower than nonfishermen families.
\end{abstract}

Key words: coastal area, family well-being, fishermen

\section{PENDAHULUAN}

Masyarakat nelayan merupakan salah satu kelompok masyarakat yang dianggap miskin bahkan paling miskin di antara penduduk miskin (the poorest of the poor). Namun demikian, data yang pasti tentang jumlah nelayan miskin di Indonesia sampai saat ini tidak pernah tersedia (Satria 2009).

Masyarakat nelayan merupakan bagian dari masyarakat yang tinggal di wilayah pesisir. Wilayah pesisir diketahui memiliki karakteristik yang unik dan memiliki keragaman potensi sumberdaya alam baik hayati maupun nonhayati yang sangat tinggi. Potensi sumberdaya yang ada dapat dimanfaatkan oleh penduduk yang tinggal di wilayah tersebut untuk mencapai kesejahteraan. Ironisnya, sebanyak 32,14\% dari 16,42 juta jiwa masyarakat pesisir masih hidup di bawah garis kemiskinan dengan indikator pendapatan US\$ 1 per hari (Direktorat PMP 2006).

Berbagai program pengentasan kemiskinan atau peningkatan kesejahteraan masyarakat telah banyak diluncurkan. Demikian pula yang menyentuh masyarakat nelayan dan masyarakat pesisir lainnya. Namun, hasilnya belum sesuai dengan harapan. Salah satu penyebabnya adalah kurang tepatnya sasaran program karena indikator yang digunakan dalam menentukan sasaran kurang akurat. Oleh karenanya, penggunaan indikator penetapan sasaran yang tepat yaitu sesuai dengan tujuan program sangat diperlukan untuk menentukan sasaran program.

Penelitian tentang kemiskinan dan kesejahteraan keluarga dengan menggunakan berbagai indikator sudah banyak 
dilakukan. Penelitian terdahulu yang telah dilakukan, khususnya menganalisis tingkat kesejahteraan keluarga secara parsial misalnya kesejahteraan keluarga nelayan (Saleha et al. 2008), keluarga di perdesaan (Suandi 2007), atau membandingkan kesejahteraan keluarga di perdesaan dan perkotaan (Papilaya 2006; Iskandar 2007; Rambe et al. 2008). Sementara itu, penelitian mengenai kesejahteraan keluarga di wilayah pesisir masih jarang dilakukan, khususnya yang membandingkan antara keluarga nelayan dengan keluarga bukan nelayan. Oleh karena itu, penelitian ini bertujuan untuk: (1) membandingkan karakteristik keluarga nelayan dan bukan nelayan di wilayah pesisir; (2) menganalisis tingkat kesejahteraan keluarga nelayan dan bukan nelayan dengan berbagai indikator; (3) menganalisis tingkat keakurasian berbagai indikator kemiskinan (sensitivitas dan spesifitas) dengan gold standard garis kemiskinan BPS; dan (4) menganalisis faktor-faktor yang mempengaruhi tingkat kesejahteraan keluarga nelayan dan bukan nelayan di wilayah pesisir Jawa Barat.

\section{METODE}

\section{Desain, Lokasi, dan Waktu}

Penelitian ini merupakan penelitian deskriptif dengan metode survei dan menggunakan data cross sectional. Penelitian dilakukan di delapan desa pada empat kecamatan pesisir di Provinsi Jawa Barat, yaitu Kecamatan Gebang (Kabupaten Cirebon) dan Kecamatan Kandanghaur (Kabupaten Indramayu) yang mewakili wilayah pesisir utara, serta Kecamatan Pelabuhanratu (Kabupaten Sukabumi) dan Kecamatan Pangandaran (Kabupaten Ciamis) yang mewakili wilayah pesisir selatan. Penelitian dilakukan mulai bulan Januari 2008 sampai dengan Maret 2009.

\section{Teknik Penarikan Contoh}

Populasi dalam penelitian ini adalah keluarga yang tinggal di wilayah pesisir kecamatan terpilih. Jumlah keluarga di empat kecamatan terpilih sebanyak 78.762 KK. Penentuan jumlah contoh mengacu pada Rumus Slovin dengan tingkat kesalahan sebesar 6\%, yaitu 276 keluarga. Untuk mengantisipasi ketidaklengkapan data, contoh dalam penelitian ini diambil sebanyak 280 keluarga.
Jenis dan Teknik Pengumpulan Data

Data yang dikumpulkan merupakan data primer. Data primer mencakup karakteristik keluarga dan tingkat kesejahteraan keluarga. Data ini diperoleh melalui wawancara dengan menggunakan kuesioner.

\section{Pengolahan dan Analisis Data}

Pengolahan data dilakukan dengan menggunakan Microsoft Excel dan SPSS for Windows. Analisis data dibedakan atas analisis deskriptif dan analisis inferensial. Analisis statistik inferensial yang digunakan adalah: (1) uji beda (uji-t dan uji Mann Whitney) untuk membandingkan karakteristik keluarga dan tingkat kesejahteraan keluarga nelayan dan bukan nelayan, (2) korelasi Pearson untuk mengetahui hubungan antar variabel penelitian, (3) uji sensitivitas dan spesifitas untuk menentukan indikator kesejahteraan yang lebih sesuai untuk wilayah pesisir, dan (4) regresi logistik untuk menganalisis faktor-faktor yang mempengaruhi tingkat kesejahteraan keluarga nelayan dan bukan nelayan.

Tingkat kesejahteraan keluarga diukur dengan menggunakan indikator kemiskinan menurut World Bank (pendapatan US\$ 1 per hari dan US\$ 2 per hari), BPS (garis kecukupan pangan dan nonpangan dan kriteria rumah tangga miskin penerima Bantuan Langsung Tunai (BLT), BKKBN (klasifikasi keluarga sejahtera dan miskin alasan ekonomi/alek), serta indikator sosial metrik dari Foundation for International Community Assistance (FINCA).

\section{HASIL DAN PEMBAHASAN}

\section{Kondisi Sosial Ekonomi Keluarga}

Berdasarkan mata pencaharian utama, keluarga di wilayah pesisir dibedakan atas keluarga nelayan dan bukan nelayan. Jumlah keluarga contoh yang termasuk dalam keluarga nelayan sebanyak 157 keluarga dan bukan nelayan sebanyak 123 keluarga. Dari seluruh keluarga contoh, hanya lebih kurang seperlima $(20,7 \%)$ yang merupakan keluarga luas. Selebihnya $(79,3 \%)$ merupakan keluarga inti. Proporsi keluarga luas pada keluarga nelayan lebih besar daripada keluarga nonnelayan. Pada keluarga nelayan, lebih dari seperlima contoh $(23,6 \%)$ termasuk dalam keluarga luas. Sementara itu, pada keluarga bukan nelayan proporsi keluarga luas hanya mencapai kurang dari seperlima (17,5\%). Meskipun demikian, tidak ada perbedaan yang 
signifikan antara tipe keluarga pada keluarga nelayan dan keluarga bukan nelayan.

Sama halnya dengan tipe keluarga, tidak ada perbedaan yang signifikan antara umur ayah, umur ibu, nilai total aset, dan pengeluaran per kapita pada keluarga nelayan dan bukan nelayan. Lain halnya dengan besar keluarga, pendidikan ayah, pendidikan ibu, dan pendapatan per kapita. Keempat karakteristik tersebut menunjukkan perbedaan yang signifikan antara keluarga nelayan dan bukan nelayan (Tabel 1 ). Rataan lama pendidikan ayah dan ibu pada keluarga nelayan lebih rendah secara signifikan daripada keluarga bukan nelayan. Sebaliknya, rataan besar keluarga dan pendapatan keluarga nelayan lebih besar secara signifikan daripada keluarga bukan nelayan.

Berdasarkan karakteristik keluarga tersebut dapat dikatakan bahwa keluarga nelayan relatif lebih tradisional dibandingkan dengan keluarga bukan nelayan. Hal ini terlihat dari banyaknya keluarga luas pada keluarga nelayan, jumlah anggota keluarga yang lebih banyak, pendidikan ayah dan ibu yang masih rendah, nilai aset yang lebih sedikit, serta rata-rata pengeluaran keluarga yang lebih rendah dibandingkan dengan keluarga bukan nelayan. Padahal jika dilihat dari pendapatan, keluarga nelayan memiliki pendapatan per kapita lebih tinggi secara signifikan daripada keluarga bukan nelayan. Secara logika jika pendapatan tinggi, maka pengeluaran juga tinggi dan tentunya akan memiliki kondisi sosial ekonomi yang lebih tinggi. Ternyata hal ini tidak berlaku bagi keluarga nelayan di wilayah pesisir Jawa Barat.
Pendapatan per kapita diperoleh dari pendapatan keluarga dibagi dengan jumlah anggota keluarga (besar keluarga). Sementara itu pendapatan keluarga merupakan penjumlahan dari seluruh pendapatan yang diperoleh seluruh anggota keluarga. Dengan demikian, pendapatan keluarga nelayan jauh lebih besar daripada pendapatan keluarga bukan nelayan. Pendapatan keluarga nelayan sebagian besar berasal dari pendapatan usaha kepala keluarga (ayah) sebagai nelayan.

Pendapatan nelayan sangat tergantung pada banyaknya hasil tangkapan yang sangat berfluktuasi sesuai dengan musim. Pada saat musim paceklik, tidak jarang para nelayan tidak memperoleh hasil sama sekali. Sebaliknya pada saat musim ikan hasil tangkapan bisa melimpah sehingga pendapatan yang diterima pun besar. Berdasarkan hasil analisis usaha dan bagi hasil pada usaha nelayan selama satu tahun, pendapatan dari penangkapan ikan sangat beragam dari Rp 100.000,00 sampai dengan Rp 15.680.000,00 per bulan. Namun, tidak seluruh pendapatan usaha ini diberikan kepada istri atau keluarganya. Pada umumnya nelayan menggunakan sebagian pendapatannya untuk belanja keperluan dirinya sendiri, misalnya untuk mencari hiburan, minum-minum atau sekadar makanmakan di warung bersama teman-teman sesama nelayan. Sehingga pendapatan yang dapat dibelanjakan untuk keperluan keluarga tinggal sisanya. Hal inilah yang menyebabkan pengeluaran per kapita keluarga nelayan lebih rendah daripada keluarga nonnelayan.

Tabel 1. Rataan dan standar deviasi besar keluarga, umur, pendidikan ayah dan ibu, serta nilai aset keluarga nelayan dan bukan nelayan di wilayah studi

\begin{tabular}{|c|c|c|c|c|c|}
\hline No & Karakteristik & Rataan Nelayan & Rataan Bukan Nelayan & Total & P-value \\
\hline 1 & Besar keluarga (orang) & $4,87 \pm 1,917$ & $4,36 \pm 1,466$ & $4,65 \pm 1,750$ & $0,014^{*}$ \\
\hline 2 & Umur ayah (th) & $43,13 \pm 10,946$ & $44,71 \pm 11,563$ & $43,8 \pm 11,220$ & 0,255 \\
\hline 3 & Umur ibu (th) & $37,47 \pm 10,083$ & $38,34 \pm 10,328$ & $37,85 \pm 10,181$ & 0,484 \\
\hline 4 & Pendidikan ayah (th) & $4,63 \pm 2,842$ & $7,17 \pm 4,436$ & $5,71 \pm 3,819$ & $0,000 * *$ \\
\hline 5 & Pendidikan ibu (th) & $4,88 \pm 2,923$ & $6,55 \pm 4,159$ & $5,61 \pm 3,605$ & 0,000 ** \\
\hline 6 & Total aset (000 $000 \mathrm{Rp})$ & $92,29 \pm 279,486$ & $156,65 \pm 438,060$ & $120,56 \pm 358,62$ & 0,158 \\
\hline 7 & Pendapatan per kapita (Rp/bulan) & $623.702,22 \pm 704.204,73$ & $434.097,36 \pm 610.038,65$ & $540.411,51 \pm 669.998,18$ & $0,017^{*}$ \\
\hline 8 & Pengeluaran per kapita (Rp/bulan) & $303.804,25 \pm 241.137,97$ & $318.462,36 \pm 249.159,60$ & $310.243,35 \pm 244.360,43$ & 0,621 \\
\hline
\end{tabular}


Kebiasaan membelanjakan pendapatan untuk keperluan pribadi ternyata tidak hanya berlaku bagi nelayan di pesisir Jawa Barat, tetapi merupakan fenomena umum sesuai dengan beberapa hasil penelitian yang menemukan bahwa laki-laki acapkali menahan sebagian pendapatannya dan membelanjakannya untuk kepentingan pribadinya (Haddad et al. 1994 dalam Falkingham \& Baschieri 2009).

\section{Kesejahteraan Keluarga}

Tabel 2 menunjukkan sebaran keluarga contoh berdasarkan kategori miskin menurut berbagai indikator. World Bank menetapkan garis kemiskinan dengan menggunakan ukuran pendapatan per kapita US\$ 1 per hari dan US\$ 2 per hari. Berdasarkan indikator ini keluarga miskin di wilayah pesisir Jawa Barat berjumlah 45,7\%. Angka ini lebih besar dari hasil penelitian SMERU pada tahun 2002 yang mengemukakan bahwa jumlah masyarakat miskin di wilayah pesisir sebanyak 43,1\%. Proporsi keluarga miskin pada kelompok nelayan lebih sedikit daripada keluarga nonnelayan. Hal ini sesuai dengan rataan pendapatan per kapita yang lebih besar pada keluarga nelayan.

Demikian halnya dengan menggunakan garis kemiskinan pedesaan di Provinsi Jawa Barat (BPS) pada tahun 2008 yaitu Rp 155.367,00 per kapita per bulan. Berdasarkan indikator itu, terlihat proporsi keluarga nelayan yang hidup di bawah garis kemiskinan lebih rendah $(13,4 \%)$ daripada keluarga bukan nelayan (17,9\%). Temuan ini tidak sesuai pernyataan Béné (2003) bahwa nelayan adalah kelompok termiskin dari penduduk miskin jika kemiskinan diukur dengan hanya dari aspek ekonomi (pendapatan dan pengeluaran).

BPS juga mengeluarkan kriteria rumah tangga miskin untuk menentukan sasaran
BLT. Rumah tangga yang termasuk miskin dan berhak menerima BLT adalah rumah tangga yang memenuhi setidaknya sembilan dari 14 kriteria yang ditetapkan. Jika menggunakan kriteria tersebut, lebih sedikit lagi keluarga nelayan yang termasuk dalam kategori miskin yaitu sebanyak 9,6\%. Bahkan keluarga bukan nelayan hanya $7,5 \%$ yang tergolong miskin.

Hal yang perlu digarisbawahi adalah jika kesejahteraan hanya diukur dengan ukuran ekonomi (pendapatan dan pengeluaran), maka keluarga nelayan dapat dikatakan lebih sejahtera daripada keluarga bukan nelayan. Namun dengan indikator yang memiliki dimensi lebih luas dan lebih menjelaskan kondisi kehidupan dari berbagai aspek (ekonomi, pendidikan, kesehatan, sosial kemasyarakatan), terlihat bahwa keluarga nelayan lebih rendah tingkat kesejahteraannya daripada keluarga bukan nelayan. Hal ini terlihat dari proporsi keluarga miskin dengan menggunakan indikator BKKBN dan sosial metrik.

Meskipun keluarga nelayan memiliki pendapatan yang relatif besar, akan tetapi penggunaan pendapatannya masih diprioritaskan pada kebutuhan dasar (pangan) dan bahkan untuk hal-hal yang kurang bermanfaat seperti rokok, jajan, atau minuman keras. Sementara itu, untuk keperluan yang mendukung investasi sumberdaya manusia seperti pendidikan dan kesehatan baik kesehatan individu maupun lingkungan perumahan kurang mendapat perhatian. Oleh karena itu, jika diukur dengan indikator yang melihat kesejahteraan dari aspek yang lebih luas seperti pendidikan, kesehatan, dan aspek spiritual, proporsi keluarga nelayan miskin menjadi lebih besar daripada keluarga nonnelayan.

Tabel 2. Sebaran keluarga contoh berdasarkan kategori miskin menurut berbagai indikator

\begin{tabular}{|c|c|c|c|c|c|c|c|c|c|c|c|c|c|}
\hline \multirow{3}{*}{ No } & \multirow{3}{*}{$\begin{array}{l}\text { Indikator } \\
\text { Kemiskinan }\end{array}$} & \multicolumn{4}{|c|}{ Nelayan } & \multicolumn{4}{|c|}{ Bukan Nelayan } & \multicolumn{4}{|c|}{ Total } \\
\hline & & \multicolumn{2}{|c|}{ miskin } & \multicolumn{2}{|c|}{ tidak miskin } & \multicolumn{2}{|c|}{ miskin } & \multicolumn{2}{|c|}{ tidak miskin } & \multicolumn{2}{|c|}{ miskin } & \multicolumn{2}{|c|}{ tidak miskin } \\
\hline & & $\mathbf{n}$ & $\%$ & $\mathbf{n}$ & $\%$ & $\mathbf{n}$ & $\%$ & $\mathbf{n}$ & $\%$ & $\mathbf{n}$ & $\%$ & $\mathbf{n}$ & $\%$ \\
\hline 1. & $\begin{array}{l}\text { World Bank (US\$ } 1 \\
\text { per hari) }\end{array}$ & 62 & 39,5 & 95 & 60,5 & 66 & 53,7 & 57 & 46,3 & 128 & 45,7 & 152 & 54,3 \\
\hline 2. & $\begin{array}{l}\text { World Bank (US\$ } 2 \\
\text { per hari) }\end{array}$ & 103 & 65,6 & 54 & 34,4 & 97 & 78,9 & 26 & 21,1 & 200 & 71,4 & 80 & 28,6 \\
\hline 3. & BPS & 21 & 13,4 & 136 & 66 & 22 & 17,9 & 101 & 82 & 43 & 15,4 & 237 & 84,6 \\
\hline 4. & BPS (BLT) & 15 & 9,6 & 142 & 90 & 9 & 7,3 & 114 & 92,7 & 24 & 8,6 & 256 & 91,4 \\
\hline 5. & BKKBN & 139 & 88,5 & 18 & 11,5 & 104 & 84,6 & 19 & 15,4 & 243 & 86,8 & 37 & 13,2 \\
\hline 6. & V (alek) & 96 & 61,1 & 61 & 38,9 & 63 & 51,2 & 60 & 48,8 & 159 & 56,8 & 121 & 43,2 \\
\hline 7. & Sosial metrik (FINCA) & 71 & 45,2 & 86 & 54,8 & 43 & 35,0 & 80 & 65,0 & 114 & 40,7 & 166 & 59,3 \\
\hline
\end{tabular}


Analisis Sensitivitas dan Spesifitas Berbagai Indikator Kesejahteraan. Analisis sensitivitas dan spesifitas digunakan untuk menilai keakurasian suatu alat ukur atau indikator dalam menjelaskan jumlah keluarga yang sejahtera atau tidak sejahtera berdasarkan ukuran yang dijadikan standar (gold standard). Dalam penelitian ini gold standard yang digunakan adalah indikator garis kemiskinan BPS yang merupakan ukuran standar nasional.

Hasil uji sensitivitas dan spesifitas yang tersaji pada Tabel 3 menunjukkan bahwa ukuran kesejahteraan yang memberikan kesalahan paling sedikit terhadap gold standard garis kemiskinan BPS pada keluarga di wilayah pesisir adalah indikator World Bank US\$ 1 per kapita dan sosial metrik dengan kesalahan masing-masing sebesar $60,6 \%$ dan $68,5 \%$. Sementara itu indikator yang memiliki bias terbesar dengan indikator garis kemiskinan BPS justru indikator yang dikeluarkan oleh BPS juga yaitu kriteria Rumah Tangga Miskin (RTM) penerima program BLT. Kriteria RTM ini lebih fokus pada kondisi rumah tinggal dan aset yang dimiliki oleh keluarga. Dengan demikian, dapat disimpulkan bahwa keluarga di wilayah pesisir tidak terlalu perhatian terhadap kondisi rumah mereka, seperti luas dan jenis lantai, penerangan, dan sumber air bersih. Hal ini tentunya akan berpengaruh pada tingkat kesehatan keluarga.

\section{Pengaruh Kondisi Sosial Ekonomi Keluarga terhadap Kesejahteraan Keluarga}

Dengan menggunakan analisis regresi logistik, diketahui bahwa secara bersamasama faktor sosial ekonomi keluarga yang terdiri dari wilayah, besar keluarga, umur kepala keluarga, pendidikan ayah, pendidikan ibu, nilai aset, pendapatan per kapita, dan pengeluaran per kapita keluarga merupakan variabel yang memiliki pengaruh yang berbeda terhadap kesejahteraan keluarga di wilayah pesisir, baik nelayan maupun nonnelayan yang diukur dengan berbagai indikator (Lampiran 1 sampai dengan Lampiran 3).

Pada keluarga nelayan, keseluruhan faktor tersebut memiliki peluang paling besar ketika menjelaskan tingkat kesejahteraan keluarga dengan indikator BLT (sebesar $79,5 \%$ ). Model tersebut juga berpeluang menjelaskan tingkat kesejahteraan BPS dan BKKBN masing-masing sebesar $70 \%$ dan $64,4 \%$. Sementara itu, kesejahteraan keluarga dengan indikator yang lain hanya dapat dijelaskan oleh faktor-faktor tersebut kurang dari $60 \%$. Bahkan untuk indikator miskin alasan ekonomi dari BKKBN faktorfaktor tersebut hanya mampu menjelaskan sebesar $20,3 \%$.

Faktor sosial ekonomi keluarga yang berpengaruh signifikan terhadap kesejahteraan keluarga nelayan bergantung kepada indikator yang digunakan. Wilayah dan umur kepala keluarga hanya berpengaruh signifikan terhadap tingkat kesejahteraan keluarga nelayan dengan indikator sosial metrik. Keduanya memiliki koefisien regresi positif, yang menunjukkan bahwa nelayan di pansela berpeluang lebih sejahtera dibandingkan dengan nelayan pantura. Selain itu, semakin tua usia kepala keluarga nelayan maka akan semakin besar peluang untuk lebih sejahtera. Hal ini terkait dengan pengalaman yang dimilikinya, semakin bertambah usia seseorang maka akan bertambah kemampuan dan pengalaman baik dalam bekerja maupun menjalani kehidupan.

Tabel 3. Sensitivitas dan spesifitas berbagai indikator kesejahteraan dengan gold standard indikator kemiskinan Garis Kemiskinan BPS

\begin{tabular}{|c|c|c|c|c|c|c|c|c|c|c|}
\hline \multirow{2}{*}{ No } & \multirow{2}{*}{ Indikator kemiskinan } & \multicolumn{3}{|c|}{ Nelayan } & \multicolumn{3}{|c|}{ Bukan Nelayan } & \multicolumn{3}{|c|}{ Total } \\
\hline & & Sv & Sp & Sv+Sp & Sv & Sp & Sv+Sp & Sv & Sp & Sv+Sp \\
\hline & World Bank (US\$ 1 per hari) & 71,4 & 65,4 & 136,8 & 86,4 & 53,5 & 139,9 & 79,1 & 60,3 & 139,4 \\
\hline & World Bank (US\$ 2 per hari) & 90,5 & 38,2 & 128,7 & 100,0 & 25,7 & 125,7 & 95,3 & 32,9 & 128,2 \\
\hline & BPS (kriteria RTM BLT) & 19,0 & 91,9 & 110,9 & 13,6 & 94,1 & 107,7 & 16,3 & 92,8 & 109,1 \\
\hline & BKKBN (keluarga sejahtera) & 95,2 & 12,5 & 107,7 & 95,5 & 17,8 & 113,3 & 95,3 & 14,8 & 110,1 \\
\hline & BKKBN (alasan ekonomi) & 95,2 & 44,1 & 139,3 & 63,6 & 51,5 & 115,1 & 79,1 & 47,3 & 127,4 \\
\hline & Sosial metrik (FINCA) & 76,2 & 59,6 & 135,8 & 59,1 & 70,3 & 129,4 & 67,4 & 64,1 & 131,5 \\
\hline
\end{tabular}

Keterangan: Sv = sensitivitas

$\mathrm{Sp}=$ spesifitas 

Besar keluarga berpengaruh negatif signifikan terhadap kesejahteraan keluarga nelayan dengan menggunakan indikator World Bank, BPS, dan BKKBN (BLT). Keluarga dengan jumlah anggota keluarga yang lebih sedikit memiliki peluang untuk lebih sejahtera dibandingkan dengan keluarga yang memiliki jumlah anggota keluarga lebih besar.

Aset keluarga memiliki pengaruh positif signifikan terhadap kesejahteraan keluarga di wilayah pesisir dengan berbagai indikator, kecuali garis kemiskinan BPS. Akan tetapi untuk keluarga nelayan, aset hanya berpengaruh jika kesejahteraan diukur dengan indikator World Bank dan sosial metrik.

Hal yang menarik adalah bahwa pendapatan bukanlah faktor yang signifikan pengaruhnya terhadap kesejahteraan dengan seluruh indikator. Hal ini menunjukkan bahwa meskipun peningkatan pendapatan penting akan tetapi tidak cukup untuk meningkatkan kesejahteraan keluarga tanpa disertai dengan perubahan mind set dan perilaku masyarakat pesisir terutama dalam investasi sumberdaya manusia seperti pendidikan dan kesehatan.

Pendidikan sangat penting digunakan sebagai instrumen bagi peningkatan kesejahteraan keluarga, karena berdasarkan berbagai literatur tentang sumberdaya manusia, pengaruh pendidikan terhadap kemiskinan tidak terbatas hanya pada hal-hal yang terkait dengan uang melalui pendapatan dan upah, akan tetapi juga menyangkut aspek yang tidak terkait dengan uang seperti kesehatan, gizi, perumahan, dan lain-lain (Zuluaga 2005).

\section{KESIMPULAN DAN SARAN}

\section{Kesimpulan}

Hasil penelitian ini menunjukkan bahwa tidak terdapat perbedaan yang signifikan dalam hal umur ayah dan ibu, total aset, dan pengeluaran per kapita pada keluarga nelayan dan bukan nelayan. Akan tetapi, keluarga nelayan memiliki jumlah anggota keluarga dan pendapatan per kapita yang lebih besar secara signifikan daripada keluarga bukan nelayan. Sebaliknya, pendidikan ayah dan pendidikan ibu pada keluarga nelayan lebih rendah dibandingkan dengan pendidikan ayah dan ibu pada keluarga bukan nelayan.

Jika kesejahteraan keluarga diukur hanya dari aspek ekonomi, maka keluarga nelayan lebih sejahtera dibandingkan dengan keluarga bukan nelayan. Sebaliknya, jika kesejahteraan diukur dengan berbagai dimensi kehidupan, maka keluarga nelayan lebih rendah tingkat kesejahteraannya.

Indikator yang memiliki sensitivitas dan spesifitas paling besar terhadap golden standard garis kemiskinan BPS untuk mengukur tingkat kesejahteraan keluarga di wilayah pesisir adalah indikator World Bank dan sosial metrik. Khusus untuk keluarga nelayan, indikator yang paling rendah biasnya terhadap garis kemiskinan BPS adalah indikator World Bank, BKKBN alasan ekonomi, dan sosial metrik.

Kondisi sosial ekonomi yang berpengaruh signifikan terhadap kesejahteraan keluarga di wilayah pesisir berbeda sesuai dengan indikator yang digunakan. Akan tetapi pada umumnya yang berpengaruh adalah besar keluarga, pendidikan, aset, pendapatan, dan pengeluaran per kapita.

\section{Saran}

Program pengentasan kemiskinan atau peningkatan kesejahteraan keluarga di wilayah pesisir akan lebih efektif jika:

1. Penetapan sasaran dengan menggunakan indikator kesejahteraan yang sesuai dengan kondisi setempat dan tujuan program.

2. Tidak hanya berupa bantuan dana untuk peningkatan pendapatan sesaat tetapi lebih diarahkan pada pengembangan usaha ekonomi keluarga.

3. Disertai dengan peningkatan kesadaran tentang pentingnya pendidikan, kesehatan, dan keluarga kecil (menggalakkan kembali program Keluarga Berencana).

4. Pemberian pelatihan mengenai manajemen keuangan keluarga.

\section{DAFTAR PUSTAKA}

Béné C. 2003. When Fishery Rhymes with Poverty: A First Step Beyond the Old Paradigm on Poverty in Small-scale Fisheries. World Development Vol.31, No. 6 pp 949-975. Great Britain: Elsevier Science Ltd. www.elsevier.com.

Direktorat PMP. 2006. 6 Tahun Program PEMP, Sebuah Refleksi. Direktorat Pemberdayaan Masyarakat Pesisir, Direktorat Jenderal Kelautan, Pesisir dan Pulau-pulau Kecil. Jakarta: Departemen Kelautan dan Perikanan. 
Falkingham J, Baschieri A. 2009. Gender and Poverty: How Misleading is the Unitary Model of Household Resources? An Illustration from Tajikistan. Global Social Policy $2009 \quad 9$ : 43. http://www.sagepub.co.uk/journalsPermi sios.nav 1468-01811.

Iskandar A. 2007. Analisis Kesejahteraan dan Manajemen Sumberdaya Keluarga di Kota dan Kabupaten Bogor. [Disertasi]. Bogor: Sekolah Pascasarjana Institut Pertanian Bogor.

Papilaya EC. 2006. Akar Penyebab Kemiskinan Menurut Rumah Tangga Miskin dan Strategi Penanggulangannya (Kasus di Kota Ambon, Propinsi Maluku dan di Kabupaten Boalemo, Propinsi Gorontalo) [Disertasi]. Bogor: Sekolah Pascasarjana Institut Pertanian Bogor.

Rambe A, Hartoyo, Karsin ES. 2008. Analisis Alokasi Pengeluaran dan Tingkat Kesejahteraan Keluarga (Studi di Kecamatan Medan Kota, Sumatera

\footnotetext{
* Korespondensi:

Telp : + $+62-2518628303$

Email : istiqlaliyah@yahoo.com
}

Utara). Jurnal IImu Keluarga \& Konsumen 1:16-28.

Saleha Q, Hartoyo, Hastuti D. 2008. Manajemen Sumberdaya Keluarga: Suatu Analisis Gender Dalam Kehidupan Keluarga Nelayan di Pesisir Bontang Kuala, Kalimantan Timur. Jurnal IImu Keluarga \& Konsumen 1:118-130.

Satria A. 2009. Laut dan Pesisir untuk Kesejahteraan Masyarakat. Bogor: IPB Press.

Suandi. 2007. Hubungan antara Sosial Capital dengan Kesejahteraan Keluarga di Daerah Perdesaan Provinsi Jambi [Disertasi]. Bogor: Sekolah Pascasarjana Institut Pertanian Bogor.

Zuluaga B. 2004. Different Channels of Impact of Education on Poverty: An Analysis for Colombia. Centre for Economic Studies_CES Katholieke Univ rsiteit Leuven and Universidad Icesi Colombia.http://ssrn.com/abstract=9586 84. 

Lampiran 1. Nilai koefisien regresi logistik pengaruh kondisi sosial ekonomi keluarga terhadap tingkat kesejahteraan keluarga nelayan (miskin=0, tidak miskin $=1$ ) di wilayah pesisir Jawa Barat $(n=157)$

\begin{tabular}{|c|c|c|c|c|c|c|c|c|c|c|c|c|c|c|c|c|c|c|}
\hline \multirow{3}{*}{ No } & \multirow{3}{*}{ Variabel independen } & \multirow{2}{*}{\multicolumn{2}{|c|}{$\begin{array}{l}\text { World Bank (US } \$ 1 \text { per } \\
\text { hari) }\end{array}$}} & \multirow{2}{*}{\multicolumn{2}{|c|}{$\begin{array}{l}\text { World Bank (US } \$ 2 \text { per } \\
\text { hari) }\end{array}$}} & \multicolumn{7}{|c|}{ Indikator kesejahteraan (0=miskin, 1=tidak miskin) } & \multirow{2}{*}{\multicolumn{3}{|c|}{ BKKBN Alek }} & \multirow{2}{*}{\multicolumn{3}{|c|}{ Sosial metrik }} \\
\hline & & & & & & \multicolumn{2}{|c|}{ Garis kemiskinan BPS } & \multicolumn{3}{|c|}{ Kriteria BLT } & \multicolumn{2}{|r|}{ BKKBN } & & & & & & \\
\hline & & $\beta$ & $\operatorname{Exp}(\beta) \quad$ Sig. & $\beta$ & Exp $(\beta) \quad$ Sig. & $\beta$ & $\operatorname{Exp}(\beta)$ & $\beta$ & $\operatorname{Exp}(\beta)$ & Sig. & $\beta$ & $\operatorname{Exp}(\beta)$ & $\beta$ & $\operatorname{Exp}(\beta)$ & Sig. & $\beta$ & $\operatorname{Exp}(\beta)$ & Sig. \\
\hline 1. & $\begin{array}{l}\text { Wilayah }(0=\text { pantura, } 1= \\
\text { pansela) }\end{array}$ & 0,518 & $1,6870,253$ & 0,069 & $1,0720,881$ & $-0,417$ & $0,6590,512$ & 0,036 & 1,037 & 0,963 & $-0,106$ & $0,8990,860$ & $-0,443$ & 0,642 & 0,284 & 0,950 & 2,585 & $0,036^{\star \star}$ \\
\hline 2. & Besar keluarga (orang) & $-0,190$ & $0,8270,058^{\star}$ & $-0,274$ & $0,7600,024^{\star \star}$ & $-0,280$ & $0,7560,019^{\star \star}$ & 0,311 & 1,365 & $0,082^{*}$ & $-0,103$ & $0,9020,450$ & $-0,127$ & 0,881 & 0,179 & $-0,033$ & 0.967 & 0,730 \\
\hline 3. & Umur ayah (tahun) & $-0,011$ & $0,9890,483$ & $-0,022$ & $0,9790,213$ & 0,028 & $1,0290,116$ & $-0,038$ & 0,965 & 0,118 & $-0,027$ & $0,9730,188$ & $-0,003$ & 0,997 & 0,851 & $-0,049$ & 0,953 & $0,004^{\star \star \star}$ \\
\hline 4. & Pendidikan ayah (tahun) & $-0,047$ & $0,9450,589$ & $-0,036$ & $0,9650,694$ & 0,141 & $1,152 \quad 0,237$ & $-0,091$ & 0,913 & 0,529 & 0,036 & $1,0360,758$ & $-0,193$ & 0,824 & $0,021^{\star \star}$ & 0,061 & 1,006 & 0,488 \\
\hline 5. & Pendidikan ibu (tahun) & 0,073 & $1,0760,395$ & 0,040 & $1,0410,637$ & 0,142 & $1,153 \quad 0,247$ & $-0,080$ & 0,923 & 0,582 & $-0,031$ & $0,9690,777$ & 0,153 & 1,166 & $0,063^{*}$ & $-0,085$ & 0,918 & 0,348 \\
\hline 6. & Aset (Rp 000 000) & 0,018 & $1,0180,004^{\star \star \star}$ & 0,007 & $1,0070,038^{\star *}$ & 0,010 & $1,0110,255$ & 0,029 & 1,029 & $0,072^{*}$ & 0,001 & $1,0010,548$ & 0,001 & 1,001 & 0,440 & 0,013 & 1,013 & $0,018^{\star \star}$ \\
\hline 7. & $\begin{array}{l}\text { Pendapatan per kapita } \\
\text { (Rp/bulan) }\end{array}$ & & & & & 0,000 & $1,0000,117$ & 0,000 & 1,000 & 0,974 & 0,000 & $1,000 \quad 0,739$ & 0,000 & 1,000 & 0,156 & 0,000 & 1,000 & 0,917 \\
\hline 8. & $\begin{array}{l}\text { Pengeluaran per kapita } \\
\text { (Rp/bulan) }\end{array}$ & 0,000 & $1,000 \quad 0,184$ & 0,000 & $1,0000,037^{\star \star}$ & & & 0,000 & 1,000 & $0,012^{\star \star}$ & 0,000 & $1,000 \quad 0,536$ & 0,000 & 1,000 & $0,030^{\star *}$ & 0,000 & 1,000 & $0,003^{\star \star \star}$ \\
\hline & Chi-square & & 45,128 & & 54,834 & & 112,309 & & 136,996 & & & 99,555 & & 24,914 & & & 50,784 & \\
\hline & df & & 7 & & 7 & & 7 & & 8 & & & 8 & & 8 & & & 8 & \\
\hline & $\mathrm{P}$ & & 0,000 & & 0,000 & & 0,000 & & 0,000 & & & 0,000 & & 0,002 & & & 0,000 & \\
\hline & Nagelkerke $\mathrm{R}^{2}$ & & 0,344 & & 0,406 & & 0,700 & & 0,795 & & & 0,644 & & 0,203 & & & 0,381 & \\
\hline
\end{tabular}

$\begin{array}{lll}\text { Keterangan: } & * & =\text { signifikan pada tingkat kepercayaan } 90 \% \\ & * *=\text { signifikan pada tingkat kepercayaan } 95 \% \\ & * \star * & =\text { signifikan pada tingkat kepercayaan } 99 \%\end{array}$ 
Lampiran 2. Nilai koefisien regresi logistik pengaruh kondisi sosial ekonomi keluarga terhadap tingkat kesejahteraan keluarga bukan nelayan (miskin=0, tidak miskin=1) di wilayah pesisir Jawa Barat $(n=123)$

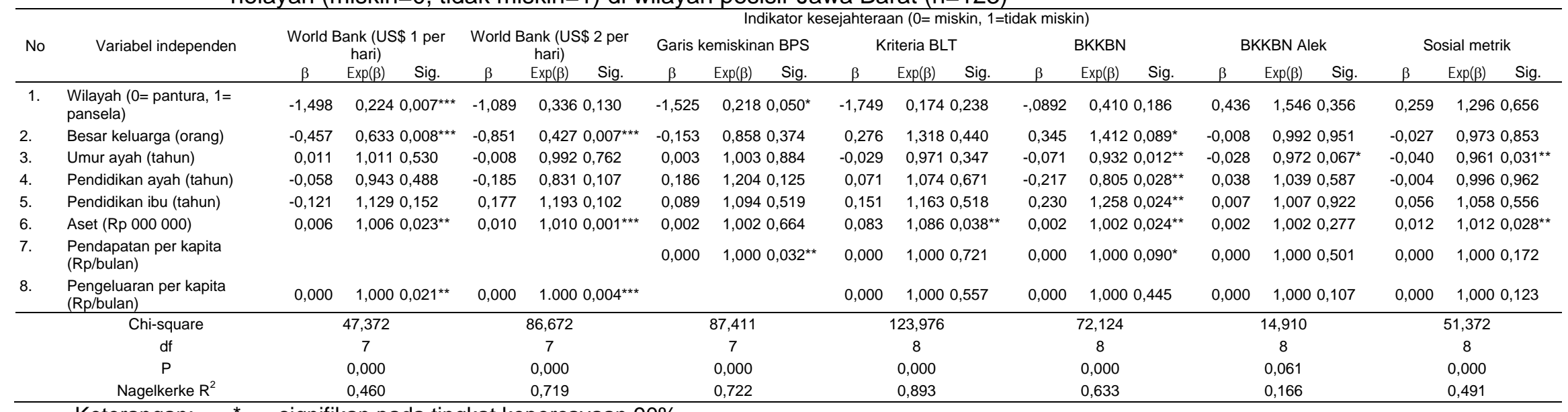

Keterangan: $\quad$ * = signifikan pada tingkat kepercayaan $90 \%$

$\star *$ = signifikan pada tingkat kepercayaan 95\%

$\star \star \star ~=~ s i g n i f i k a n ~ p a d a ~ t i n g k a t ~ k e p e r c a y a a n ~ 99 \%$ 
Lampiran 3. Nilai koefisien regresi logistik pengaruh kondisi sosial ekonomi keluarga terhadap tingkat kesejahteraan keluarga nelayan dan bukan nelayan (miskin $=0$, tidak miskin $=1)$ di wilayah pesisir Jawa Barat $(n=280)$

\begin{tabular}{|c|c|c|c|c|c|c|c|c|c|c|c|c|c|c|c|c|c|c|c|c|c|c|}
\hline \multirow{3}{*}{ No } & \multirow{3}{*}{ Variabel independen } & \multirow{2}{*}{\multicolumn{3}{|c|}{$\begin{array}{c}\text { World Bank (US\$1 per } \\
\text { hari) }\end{array}$}} & \multirow{2}{*}{\multicolumn{3}{|c|}{$\begin{array}{c}\text { World Bank (US\$2 per } \\
\text { hari) }\end{array}$}} & \multicolumn{9}{|c|}{ Indikator kesejahteraan ( $0=$ miskin, $1=$ tidak miskin) } & \multirow{2}{*}{\multicolumn{3}{|c|}{ BKKBN Alek }} & \multirow{2}{*}{\multicolumn{3}{|c|}{ Sosial metrik }} \\
\hline & & & & & & & & \multicolumn{3}{|c|}{ Garis kemiskinan BPS } & \multicolumn{3}{|c|}{ Kriteria BLT } & \multicolumn{3}{|c|}{ BKKBN } & & & & & & \\
\hline & & $\beta$ & $\operatorname{Exp}(\beta)$ & Sig. & $\beta$ & $\operatorname{Exp}(\beta)$ & Sig. & $\beta$ & $\operatorname{Exp}(\beta)$ & Sig. & $\beta$ & $\operatorname{Exp}(\beta)$ & Sig. & $\beta$ & $\operatorname{Exp}(\beta)$ & Sig. & $\beta$ & $\operatorname{Exp}(\beta)$ & Sig. & $\beta$ & $\operatorname{Exp}(\beta)$ & Sig. \\
\hline 1. & $\begin{array}{l}\text { Wilayah }(0=\text { pantura, } 1= \\
\text { pansela) }\end{array}$ & $-0,158$ & 0,854 & 0,610 & 0,024 & 1,024 & 0.945 & $-0,947$ & 0,388 & $0,041^{\star *}$ & $-0,279$ & 0,757 & 0,640 & $-0,304$ & 0,738 & 0,434 & $-0,219$ & 0,803 & 0,432 & 0,643 & 1,903 & $0,058^{\star}$ \\
\hline 2. & Besar keluarga (orang) & $-0,173$ & 0,842 & $0,023^{\star \star}$ & $-0,297$ & 0,743 & $0,005^{\star \star \star}$ & $-0,201$ & 0,818 & $0,027^{\star \star}$ & 0,247 & 1,280 & $0,088^{\star}$ & $-0,007$ & 0,993 & 0,947 & $-0,086$ & 0,917 & 0,222 & $-0,072$ & 0,930 & 0,340 \\
\hline 3. & Umur ayah (tahun) & $-0,011$ & 0,989 & 0,296 & $-0,027$ & 0,973 & $0,046^{\star *}$ & 0,016 & 1,016 & 0,231 & $-0,032$ & 0,969 & $0,061^{\star}$ & $-0,038$ & 0,962 & $0,006^{\star \star \star}$ & $-0,012$ & 0,988 & 0,210 & $-0,040$ & 0,961 & $0,001^{\star \star \star}$ \\
\hline 4. & Pendidikan ayah (tahun) & $-0,088$ & 0,916 & 0,111 & $-0,125$ & 0,883 & $0,041^{* *}$ & 0,164 & 1,179 & $0,043^{\star \star}$ & $-0,018$ & 0,962 & 0,857 & $-0,077$ & 0,926 & 0,252 & $-0,049$ & 0,952 & 0,326 & 0,037 & 1,031 & 0,543 \\
\hline 5. & Pendidikan ibu (tahun) & 0,075 & 1,078 & 0,193 & 0,064 & 1,056 & 0,298 & 0,091 & 1,095 & 0,294 & $-0,009$ & 1,009 & 0,935 & 0,086 & 1,090 & 0,204 & 0,089 & 1,093 & $0,089^{*}$ & $-0,014$ & 0,986 & 0,826 \\
\hline 6. & Aset (Rp 000 000) & 0,007 & 1,007 & $0,007^{\star \star \star}$ & 0,006 & 1,006 & $0,001^{\star \star \star}$ & 0,005 & 1,005 & 0,333 & 0,038 & 1,038 & $0,006^{\star \star \star}$ & 0,001 & 1,001 & $0,009^{\star \star \star}$ & 0,001 & 1,001 & $0,078^{\star}$ & 0,013 & 1,014 & $0,000^{\star \star \star}$ \\
\hline 7. & $\begin{array}{l}\text { Pendapatan per kapita } \\
\text { (Rp/bulan) }\end{array}$ & & & & & & & 0,000 & 1,000 & $0,003^{\star \star \star}$ & 0,000 & 1,000 & 0,633 & 0,000 & 1,000 & 0,431 & 0,000 & 1,000 & $0,008^{\star \star \star}$ & 0,000 & 1,000 & 0,975 \\
\hline \multirow[t]{5}{*}{8.} & $\begin{array}{l}\text { Pengeluaran per kapita } \\
\text { (Rp/bulan) }\end{array}$ & 0,000 & 1,000 & $0,000^{\star \star \star}$ & 0,000 & 1,000 & $0,000^{* \star \star}$ & & & & 0,000 & 1,000 & $0,006^{\star \star \star}$ & 0,000 & 1,000 & $0,036^{\star *}$ & 0,000 & 1,000 & $0,074^{*}$ & 0,000 & 1,000 & $0,000^{\star \star \star}$ \\
\hline & Chi-square & & 67,151 & & & 123,458 & & & 193,139 & & & 256,136 & & & 161,712 & & & 28,897 & & & 96,570 & \\
\hline & df & & 7 & & & 7 & & & 7 & & & 8 & & & 8 & & & 8 & & & 8 & \\
\hline & $P$ & & 0,000 & & & 0,000 & & & 0,000 & & & 0,000 & & & 0,000 & & & 0,000 & & & 0,000 & \\
\hline & Nagelkerke $\mathrm{R}^{2}$ & & 0,300 & & & 0,500 & & & 0,694 & & & 0,830 & & & 0,612 & & & 0,139 & & & 0,410 & \\
\hline
\end{tabular}

Keterangan: $\quad * \quad=$ signifikan pada tingkat kepercayaan $90 \%$

** = signifikan pada tingkat kepercayaan 95\%

$\star * *=$ signifikan pada tingkat kepercayaan $99 \%$ 